\title{
FAKTOR-FAKTOR YANG MEMPENGARUHI STATUS GIZI ANAK AUTIS DI SEKOLAH KEBUTUHAN KHUSUS KOTA KEDIRI
}

\author{
SUWOYO \\ Poltekes Kemenkes Malang Prodi Kebidanan Kediri \\ Email: suwoyosukijar@yohoo.com
}

\begin{abstract}
The prevalence of autism in Indonesia continues to increase. Children with autism have limited choices of food that may be consumed. This limitation can affect the low or excess intake of nutrients needed by children with autism. Various factors can affect the nutritional status of children with autism. One of them is the pattern of consumption of foods that do not diet GFCF. This study aims to determine the factors that affect nutritional status in children with autism in the School of Special Needs, Kediri. The design used was cross sectional analytic. The population in this study were all children with autism in the School of Special Needs, Kediri, as many as 31 children. The sampling technique used was simple random sampling, with a sample size of 29 children with autism. The result of ordinal regression test to analyze the influence of knowledge on nutritional status was obtained $\mathrm{p}=0,038<\alpha(0,05)$, socio-economic influence with nutritional status got $\mathrm{p}=$ $0,004<\alpha(0,05)$, influence of education level with nutrient status got $p=0,412>\alpha(0,05)$, and the effect of activity pattern with nutritional status obtained $p=0,059 n>\alpha(0,05)$. The conclusion of this research is that based on the results of spearmen test, $s$ then the variables of education, socioeconomic and educational level have correlation with nutritional status of autistic children, while the activity pattern variable is not related to nutritional status of children with autism. Based on testing of ordinal regression analysis it is found that knowledge and socioeconomic of parents influence nutritional status, sedagkan level of education and activity pattern does not affect nutritional status. Therefore, parents at home and school teachers have a very strategic role in providing nutritional intake according to the needs of children with autism, and set the pattern of activities both controlled and uncontrolled.
\end{abstract}

Keywords: factors that affect Nutrition Status, Autis Children

\section{PENDAHULUAN}

Anak memiliki suatu ciri khas yaitu selalu tumbuh dan berkembang sejak konsepsi sampai berakhirnya masa remaja (Rusmil, 2006). Pada beberapa kondisi terdapat anak - anak yang mengalami masalah perkembangan, baik secara fisik maupun mental. Masalah perkembangan itu misalnya idiot, embisil, debil, slow leaner, dan autis (Winarno, 2011).

Autis adalah gangguan perkembangan pervasif pada anak yang ditandai dengan adanya gangguan dan keterlambatan dalam bidang kognitif, bahasa, perilaku, komunikasi dan interaksi sosial (Wong, 2009).Masalah utama dari autis ada tiga yaitu otak, racun dan fungsi pencernaannya. Penyebab yang pasti dari autis tidak diketahui, yang pasti hal ini bukan disebabkan oleh pola asuh yang salah. Penelitian terbaru menitik beratkan pada kelainan anatomis di otak, zat-zat adiktif, faktor genetik dan gangguan sistem pencernaan (Sunu, 2012).

Autis dapat terjadi pada seluruh anak dari berbagai tingkat sosial dan kultur (Wijayakusuma, 2004). Berdasarkan laporan yang didapat, prevalansi autis di dunia saat ini mencapai $15-20$ kasus per 10.000 anak atau 0,15-0,20\% (Mashabi NA. \& Tajudin NR, 2009). Sedangkan, menurut data yang diperoleh Menteri Kesehatan Indonesia, terus terjadi peningkatan jumlah penderita autis di 
Indonesia. Pada tahun tahun 2003 hanya 1:10.000 anak, sedangkan pada tahun 2004 diperkirakan 1 dari 150 anak yang menderita autis. Berdasarkan data yang diperoleh dr. Widodo Judarwanto Sp.An pada tahun 2006 menyatakan bahwa diperkirakan jumlah anak autis di Indonesia mencapai 150 - 200 ribu orang. Apabila angka kelahiran di Indonesia enam juta per tahun, maka jumlah penyandang autis di Indonesia bertambah $0,15 \%$ atau 6.900 anak pertahun (Mashabi NA. \& Tajudin NR, 2009).

Menurut laporan dari Ketua Yayasan Autis Indonesia menyatakan adanya peningkatan jumlah anak autis. Pada tahun 2000 jumlah penyandang autis di Indonesia diperkirakan 1: 5000 anak, sedangkan pada tahun 2010 meningkat menjadi 1 : 500 anak (Moore, 2010 dalam Aprila, 2012).

Menurut Kepala Dinas Pendidikan Jawa Timur Suwanto di Jawa Timur tahun 2009 terdapat 93 sekolah inklusi dengan siswa berkebutuhan khusus 1.476 anak dan $15 \%$ diantaranya adalah anak autis. Berdasarkan hasil study pendahuluan yang dilakukan pada tanggal 1 Juni 2015 di sekolah kebutuhan khusus kota Kediri didapatkan hasil dari total siswa $80 \%$ peyandang autis dan $20 \%$ bukan anak autis (tuna wicara, tuna rungu, hiperaktif, tuna grahita).

Anak autis memerlukan pendidikan khusus. Sekolah pendidikan khusus adalah pendidikan dengan pendekatan khusus yang berusaha menstransformasi sistem pendidikan dengan meniadakan hambatan-hambatan yang dapat menghalangi setiap siswa untuk berpartisipasi penuh pada pendidikan. Hambatan yang ada bisa terkait dengan masalah etnik, gender, status sosial, dan sebagainya. Sekolah pendidikan khusus berupaya untuk mengoptimalkan potensi anak (Satrio,2016).

Anak autis memiliki keterbatasan dalam makanan yang dikonsumsi. Keterbatasan ini dapat mempengaruhi rendahnya atau berlebihnya asupan zat gizi yang dibutuhkan anak autis (Andyca, 2012). Menurut temuan Andyca (2012) di Universitas Indonesia status gizi pada anak autis dikategorikan menjadi lima yaitu kegemukan $(25,8 \%)$, kelebihan berat badan $(17,7 \%)$, normal $(51,6 \%)$, sangat kurus $(4,8 \%)$, dan kurus $(0 \%)$. Tapi untuk analisis data berikutnya, Andyca menggolongkan status gizi menjadi dua kelompok yaitu berat badan normal (termasuk status gizi kurus dan sangat kurus) $(56,5 \%)$ dibanding kelebihan berat badan (termasuk obesitas) $(43,5 \%)$.

Overweight dan obesitas merupakan resiko kelima kejadian di dunia (WHO, 2006). Kelebihan berat badan atau overweight merupakan masalah gizi lebih yang saat ini banyak ditemukan. Dalam penelitian yang dipublikasikan oleh $B M C$ Pediatric pada bulan Desember 2005, menyatakan kelebihan berat badan pada anak autis dapat disebabkan oleh pola konsumsi yang tidak biasa, tidak biasa diet dan menurunya akses untuk melakukan aktifitas fisik. Menurut penelitian Andyca (2012) ditemukan kelebihan berat badan lebih banyak ditemukan pada anak yang tidak melakukan diet GFCF (46,2\%) dibandingkan anak yang melakukan diet GFCF $(41,7 \%)$.

Kelebihan berat badan dapat meningkatnya risiko penyakit jantung dan pembuluh darah, diabetes tipe 2 , masalah tulang, dan gangguan tidur. Selain itu, keberadaan penyandang autis masih belum sepenuhnya bisa diterima di tengah masyarakat (Zuhriarsih, 2010).

Berdasarkan fenomena diatas, menjadi dasar bagi peneliti untuk melakukan penelitian yang berjudul " Faktor-faktor yang mempengaruhi Status Gizi Pada Anak Autis Di Sekolah Kebutuhan Khusus Kota Kediri

\section{METODE PENELITIAN}

Desain penelitian yang digunakan dalam penelitian ini adalah cros seksional, dimana dimana variabel dipenden dan 
independen diamati dalam waktu yang sama. Populasi dalam penelitian ini adalah semua anak autis di Sekolah Kebutuhan Khusus Kota Kediri, sebanyak 31 anak autis. Sampel dalam penelitian ini adalah sebagian anak autis di Sekolah Kebutuhan Khusus Kota Kediri.

\section{Besar Sampel}

Untuk populasi kecil atau kurang dari 1000, dapat menggunakan rumus :

$$
n=\frac{N}{1+N\left(d^{2}\right)}
$$

Keterangan:

$\mathrm{n}=$ Besar sampel

$\mathrm{N}=$ Besar populasi

$\mathrm{d}=$ Tingkat kepercayaan/ ketepatan yang diinginkan $(\mathrm{d}=0,05)$

(Nursalam, 2009)

Berdasarkan rumus tersebut, didapatkan besar sampel :

$$
\begin{aligned}
n & =\frac{31}{1+31\left(0,05^{2}\right)} \\
& =29 \text { anak autis }
\end{aligned}
$$

Dalam penelitian ini, teknik pengambilan sampel yang digunakan adalah simple random sampling. Penelitian ini dilaksanakan di Sekolah Berkebutuhan Khusus Kota Kediri Penelitian ini dilaksanakan pada 17 Oktober sampai 31 Oktober 2016

Variabel bebas dalam penelitian ini adalah faktor-faktoryang memepengaruhi status gizi. Variabel tergantung dalam penelitian ini adalah status gizi anak autis.

Instrumen yang digunakan dalam penelitian ini adalah berupa kuesioner yang berisi pertanyaan-pertanyaan . Untuk data status gizi menggunakan timbangan injak (Seca) untuk mengukur berat badan, dengan ketelitian $0,1 \mathrm{~kg}$ dan nilai maksimum $120 \mathrm{~kg}$, Microtoise untuk mengukur tinggi badan, dengan ketelitian $0,1 \mathrm{~mm}$ dan nilai maksimum $200 \mathrm{~cm}$, dan tabel Z_Score untuk mencocokan Index Masa Tubuh (IMT) dibanding umur.

Dalam penelitian ini analisis univariat bertujuan untuk mengetahui distribusi frekwensi pengetahuan orang tua, sosial ekonomi, tingkat pendidikan orang tua dan pola aktifitas anak.

Untuk mengetahui faktor-faktor yang berpengaruh terhadap status gizi anak autis dengan menggunakan Regrisi Logistik Ganda.

\section{HASIL PENELITIAN}

Dari hasil pengumpulan data yang dilaksanakan pada tanggal 17 Oktober sampai dengan 31 Oktober 2016 di Sekolah Kebutuhan Khusus kota Kediri didapatkan 29 responden sebagai sampel penelitian. Pengumpulan data dilakukan pada tiga Sekolah Kebutuhan Khusus di Kota Kediri, yaitu Ananda Putra Madiri, di Jalan Penangungan, No 6 Kediri, Cahaya Harapan, di Jalan Dworowati, No. 2 Mrican Kota Kediri, dan Tumbuh Bersama Griya Mauni, Kelurahan Bangsal Kota Kediri.

Data yang telah dikumpulkan selanjutnya dianalisis untuk mengetahui faktor-faktor yang mempengaruhi status gizi anak autis. Variabel yang diamati dalam penelitian ini adalah pengetahuan orang tua tentang diet anak autis, sosial ekonomi orang tua, pendidikan orang tua dan pola aktifitas anak terhadap status gizi anak autis. Hasil pengumpulan data secara rinci akan disampaikan seperti berikut ini

\section{Pengaruh Pengetahuan Orang Tua Tentang Diet Dengan status Gizi Anak Autis}

Berdasarkan data yang dikumpukan dari 29 responden, pengetahuan orang tua tentang diet anak autis, didapatkan 9 responden $(31,05 \%)$ berpengetahuan baik, 8 responden $(27,65 \%)$ berpengetahuan cukup, dan 12 responden $(41,4 \%)$ berpengetahuan kurang (data selengkapnya dapat dilihat pada lampiran 1). Tabulasi silang pengetahuan orang tua tentang diet dengan status gizi anak autis ditunjukkan pada tabel 4.1 dibawah ini. 
Tabel 4.1 Tabulasi Silang Pegetahuan Orang Tua Tentang Diet Dengan Status Gizi Anak autis

\begin{tabular}{|c|c|c|c|c|c|c|c|c|}
\hline Rengetahuan & \multicolumn{2}{|c|}{ Baik } & \multicolumn{2}{|c|}{ Cukup } & \multicolumn{2}{|c|}{ Kurang } & \multicolumn{2}{|c|}{ Total } \\
\hline Status gizi & $\mathrm{n}$ & $\%$ & $\mathrm{n}$ & $\%$ & $\mathrm{n}$ & $\%$ & $\mathrm{n}$ & $\%$ \\
\hline Kegemukan & 0 & 0 & 0 & 0 & 0 & 0 & 0 & 0 \\
\hline $\begin{array}{l}\text { Kelebihan } \\
\text { BB }\end{array}$ & 0 & 0 & 2 & 6,9 & 0 & 0 & 2 & 6,9 \\
\hline Normal & 8 & 27,6 & 5 & 17,2 & 4 & $\begin{array}{l}13, \\
8\end{array}$ & 17 & $\begin{array}{l}58, \\
6\end{array}$ \\
\hline Kurus & 1 & 3,45 & 1 & 3,45 & 8 & $\begin{array}{l}27, \\
6\end{array}$ & 10 & $\begin{array}{l}34, \\
5\end{array}$ \\
\hline Sangat kurus & 0 & 0 & 0 & 0 & 0 & 0 & 0 & 0 \\
\hline Total & 9 & $\begin{array}{l}31,0 \\
5\end{array}$ & 8 & $\begin{array}{l}27,6 \\
5\end{array}$ & 12 & $\begin{array}{l}41, \\
4\end{array}$ & 29 & $\begin{array}{l}10 \\
0\end{array}$ \\
\hline
\end{tabular}

selanjutnya dilakukan uji spearman's rho untuk mengetahui hubungan pengetahuan orang tua tentang diet terhadap status gizi anak autis. Dari hasil hitungan didapatkan nilai signifikansi $\mathrm{p}=0,027<\propto(0,05)$ (hasil hitungan dapat dilihat pada lampiran 6). Sehingga dapat disimpulkan ada hubungan antara pengetahuan orang tua tentang diet dengan status gizi anak autis.

Selanjutnya variabel tersebut dilakukan analisis dengan menggunakan ordinal regression untuk mengetahui pengaruh faktor tersebut terhadap status gizi anak autis. Berdasarkan pengujian analisis ordinal regression didapatkan nilai signifikansi variabel pengetahuan ibu tentang status gizi anak autis adalah $\mathrm{p}=$ $0,03<\propto(0,05)$, artinya variabel pengatahuan mempengaruhi status gizi anak autis.

\section{Pengaruh Sosial Ekonomi Dengan Status Gizi Anak Autis}

Berdasarkan data yang dikumpukan dari 29 responden, sosil ekonomi orang tua anak dengan autis, didapatkan 10 responden $(34,5 \%)$ sosial ekonomi tinggi, 8 responden $(27,55 \%)$ sosial ekonomi sedang, dan 11 responden $(37,95 \%)$ sosial ekonomi rendah (data selengkapnya dapat dilihat pada lampiran 2). Tabulasi silang sosial ekonomi Dengan status gizi anak autis ditunjukkan pada tabel 4.2 dibawah ini.
Tabel 4.2

Orang Tua

Tabulasi Silang Sosial Ekonomi

Dengan Status Gizi Anak autis

\begin{tabular}{|c|c|c|c|c|c|c|c|c|}
\hline \multirow{2}{*}{ Status gizi } & \multicolumn{2}{|c|}{ Tinggi } & \multicolumn{2}{|c|}{ Sedang } & \multicolumn{2}{|c|}{ rendah } & \multicolumn{2}{|c|}{ Total } \\
\hline & $\mathrm{n}$ & $\%$ & $\mathrm{n}$ & $\%$ & $\mathrm{n}$ & $\%$ & $\mathrm{n}$ & $\%$ \\
\hline Kegemukan & 0 & 0 & 0 & 0 & 0 & 0 & 0 & 0 \\
\hline Kelebihan BB & 1 & 3,45 & 1 & 3,45 & 0 & 0 & 2 & 6,9 \\
\hline Normal & 9 & 31,05 & 5 & 17,2 & 3 & 10,35 & 17 & $\begin{array}{l}58, \\
6\end{array}$ \\
\hline Kurus & 0 & 0 & 2 & 6,9 & 8 & 27,6 & 10 & $\begin{array}{l}34, \\
5\end{array}$ \\
\hline Sangat kurus & 0 & 0 & 0 & 0 & 0 & 0 & 0 & 0 \\
\hline Total & 10 & 34,5 & 8 & 27,55 & 11 & 37,95 & 29 & 100 \\
\hline
\end{tabular}

Berdasarkan data tersebut, selanjutnya dilakukan uji spearman's rho untuk mengetahui hubungan sosial ekonomi orang tua terhadap status gizi anak autis. Dari hasil hitungan didapatkan nilai signifikansi $\mathrm{p}=0,00<\propto(0,05)$ (hasil hitungan dapat dilihat pada lampiran 6). Sehingga dapat disimpulkan ada hubungan sosil ekonomi orang tua dengan status gizi anak autis.

Selanjutnya variabel tersebut dilakukan analisis dengan menggunakan ordinal regression untuk mengetahui pengaruh faktor tersebut terhadap status gizi anak autis.Variabel pendapatan atau sosial ekonomi keluarga didapatkan nilai signifikansi $\mathrm{p}=0,04<\propto(0,05)$, artinya variabel variabel sosial ekonomi mempengaruhi status gizi anak autis

\section{Pengaruh Tingkat Pendidikan Orang Tua Dengan Status Gizi anak autis}

Berdasarkan data yang dikumpukan dari 29 responden, tingkat pendidikan orang tua anak dengan autis, didapatkan 5 responden $(17,25 \%)$ berpendidikan tinggi, 15 responden $(51,7 \%)$ berpendidikan menengah, dan 9 responden $(31,04 \%)$ berpendidikan dasar (data selengkapnya dapat dilihat pada lampiran 3). Tabulasi 
silang pendidikan orang tua dengan status gizi anak autis ditunjukkan pada tabel 4.3 dibawah ini.

Tabel 4.3 Tabulasi Silang Tingkat Pendidikan Orang Tua Dengan Status Gizi Anak autis

\begin{tabular}{|c|c|c|c|c|c|c|c|c|}
\hline \multirow{3}{*}{ Status gizi } & \multicolumn{2}{|c|}{ Tinggi } & \multicolumn{2}{|c|}{$\begin{array}{l}\text { Menenga } \\
\mathrm{h}\end{array}$} & \multicolumn{2}{|c|}{ Dasar } & \multicolumn{2}{|c|}{ Total } \\
\hline & $\mathrm{n}$ & $\%$ & $\mathrm{n}$ & $\%$ & $\mathrm{n}$ & $\%$ & $\mathrm{n}$ & $\%$ \\
\hline & & & & & & & & \\
\hline Kegemukan & 0 & 0 & 0 & 0 & 0 & 0 & 0 & 0 \\
\hline Kelebihan & 1 & 3,4 & 1 & 3,4 & 0 & 0 & 2 & 6,9 \\
\hline $\mathrm{BB}$ & & 5 & & 5 & & & & \\
\hline Normal & 3 & $\begin{array}{l}10, \\
35\end{array}$ & 11 & $\begin{array}{l}37, \\
9\end{array}$ & 3 & $\begin{array}{l}10, \\
35\end{array}$ & 17 & $\begin{array}{l}58, \\
6\end{array}$ \\
\hline Kurus & 1 & $\begin{array}{l}3,4 \\
5\end{array}$ & 3 & $\begin{array}{l}10, \\
35\end{array}$ & 6 & $\begin{array}{l}20, \\
69\end{array}$ & 10 & $\begin{array}{l}34, \\
5\end{array}$ \\
\hline Sangat kurus & 0 & 0 & 0 & 0 & 0 & 0 & 0 & 0 \\
\hline Total & 5 & $\begin{array}{l}17, \\
25\end{array}$ & 15 & $\begin{array}{l}51, \\
7\end{array}$ & 9 & $\begin{array}{l}31, \\
04\end{array}$ & 29 & $\begin{array}{l}10 \\
0\end{array}$ \\
\hline
\end{tabular}

Berdasarkan data tersebut,
selanjutnya dilakukan uji spearman's rho untuk mengetahui hubungan tingkat pendidikan orang tua dengan status gizi anak autis. Dari hasil hitungan didapatkan nilai signifikansi $\mathrm{p}=0,018<\propto(0,05)$ (hasil hitungan dapat dilihat pada lampiran 6). Sehingga dapat disimpulkan ada hubungan sosial ekonomi orang tua dengan status gizi anak autis.

Selanjutnya variabel tersebut dilakukan analisis dengan menggunakan ordinal regression untuk mengetahui pengaruh faktor tersebut terhadap status gizi anak autis. Hasil analisis variabel tingkat pendidikan mendapatkan nilai signifikansi $\mathrm{p}=0,412>\propto(0,05)$, artinya variabel tingkat pendidikan orang tua anak dengan autis tidak mempengaruhi status gizi anak autis.

\section{Pengaruh Pola aktifitas Anak Dengan Status Gizi Anak Autis}

Berdasarkan data yang dikumpukan dari 29 responden, pola aktifitas anak dengan autis, didapatkan 1 responden $(3,45 \%)$ pola aktifitas hiperaktif, 28 responden $(96,55 \%)$ pola aktifitas aktif, dan 0 responden $(0 \%)$ pola aktiditas hipoaktif (data selengkapnya dapat dilihat pada lampiran 4). Tabulasi silang pola aktifitas anak dengan status gizi anak autis ditunjukkan pada tabel 4.4 dibawah ini.

Tabel 4.4 Tabulasi Silang Pola Aktifitas Anak Dengan Status Gizi Anak autis

\begin{tabular}{|c|c|c|c|c|c|c|c|c|}
\hline \multirow{3}{*}{ Status gizi } & \multicolumn{2}{|c|}{ Hiperaktif } & \multicolumn{2}{|c|}{ Aktif } & \multicolumn{2}{|c|}{ Hipoaktif } & \multicolumn{2}{|c|}{ Total } \\
\hline & $\mathrm{n}$ & $\%$ & $\mathrm{n}$ & $\%$ & $\mathrm{n}$ & $\%$ & $\mathrm{n}$ & $\%$ \\
\hline & & & & & & & & \\
\hline Kegemukan & 0 & 0 & 0 & 0 & 0 & 0 & 0 & 0 \\
\hline Kelebihan BB & 0 & 0 & 2 & 6,9 & 0 & 0 & 2 & 6,9 \\
\hline Normal & 1 & 3,45 & $\begin{array}{l}1 \\
6\end{array}$ & $\begin{array}{l}55, \\
17\end{array}$ & 0 & 0 & 17 & 58,62 \\
\hline Kurus & 0 & 0 & $\begin{array}{l}1 \\
0\end{array}$ & $\begin{array}{l}34, \\
48\end{array}$ & 0 & 0 & 10 & 34,48 \\
\hline Sangat kurus & 0 & 0 & 0 & 0 & 0 & 0 & 0 & 0 \\
\hline Total & 1 & 3,45 & $\begin{array}{l}2 \\
8\end{array}$ & $\begin{array}{l}96, \\
55\end{array}$ & 0 & 0 & 29 & 100 \\
\hline
\end{tabular}

Berdasarkan data tersebut, selanjutnya dilakukan uji spearman's rho untuk mengetahui hubungan pola aktifitas anak dengan status gizi anak autis. Dari hasil hitungan didapatkan nilai signifikansi $\mathrm{p}=0,592>\propto(0,05)$ (hasil hitungan dapat dilihat pada lampiran 7). Sehingga dapat disimpulkan tidak ada hubungan pola aktifitas anak dengan status gizi anak autis.

Selanjutnya variabel tersebut dilakukan analisis dengan menggunakan ordinal regression untuk mengetahui pengaruh faktor tersebut terhadap status gizi anak autis. Hasil analisis variabel pola aktifitas anak mendapatkan nilai signifikansi $p=0,059>\propto(0,05)$, artinya variabel pola aktifitas anak tidak mempengaruhi status gizi anak autis

\section{Faktor-faktor Yang Mempengaruhi Status Gizi Anak Autis}

Berdasarkan hasil penelitian yang dilakukan, pada 29 responden di sekolah kebutuhan khusus kota Kediri menunjukkan adanya hubungan antara tingkat pengetahuan, tingkat pendidikan, 
sosial ekonomi dengan status gizi anak autis. Tetapi variabel tingkat aktifitas anak, menunjukkan tidak ada hubungan tingkat aktifitas anak dengan status gizi anak autis.

Selanjutnya variabel-variabel tersebut dilakukan analisis dengan menggunakan ordinal regression untuk mengetahui faktor-faktor yang berpengaruh terhadap status gizi anak autis. Berdasarkan pengujian analisis ordinal regression maka variabel independent yang mempengaruhi variabel dependent adalah pengetahuan dan pendapatan. Hal ini ditunjukkan dari hasil analisis tersebut didapatkan nilai signifikansi variabel pengetahuan ibu tentang status gizi anak autis adalah $\mathrm{p}=$ $0,03<\propto(0,05), \quad$ artinya variabel pengatahuan mempengaruhi status gizi anak autis. Variabel pendapatan atau sosial ekonomi keluarga didapatkan nilai signifikansi $\mathrm{p}=0,04<\propto(0,05)$, artinya variabel variabel sosial ekonomi mempengaruhi status gizi anak autis. Sedangkan variabel tingkat pendidikan mendapatkan nilai signifikansi $\mathrm{p}=0,412$ $>\propto(0,05)$, dan variabel aktifitas anak mendapatkan nilai signifikansi $\mathrm{p}=0,059$ $>\propto((0,05)$, artinya variabel tingkat pendidikan dan aktivitas anak tidak mempengaruhi status gizi anak autis.

\section{PEMBAHASAN}

Pengaruh Pengetahuan Orang Tua Tentang Diet Dengan status Gizi Anak Autis

Peran orang tua dalam pengaturan pola makan anak sangat penting. Orang tua diharapkan mempunyai pengetahuan yang baik tentang gizi bagi anaknya, terlebih anak yang membutuhkan perhatian khusus seperti anak autis. Sehingga orang tua akan bisa memberikan diet yang tepat, dengan harapan anak tidak kekurangan atau kelebihan pemenuhan gizi yang berdampak pada tumbuh kembangnya.

Berdasarkan hasil penelitian yang dilakukan disekolah kebutuhan khusus kota Kediri, didapatkan bahwa $\mathrm{p}=0,027<$ $\propto(0,05)$ artinya ada hubungan antara pengetahuan orang tua dengan status gizi anak autis. Hal ini menunjukkan bahwa status gizi anak, ditentukan bagaimana pengetahuan orang tuanya tentang diet bagi anaknya. Sehingga peran orang tua mempunyai andil yang besar dalam menentukan status gizi bagi anaknya.

Menurut Elder (2006), peran orang tua pada terapi yang sangat dibutuhkan yaitu pengawasan yang ketat pada pola makan anak. Penerapan diet harus dilakukan secara tepat, teratur dan terus menerus untuk melihat manfaat penuh dari diet. Pengawasan yang ketat sangat diperlukan dalam mengatur pola makan anak, dan kurangnya pengawasan tersebut dapat berpengaruh terhadap penerapan diet GFCF (Thompson dalam Washineski 2009).

Meskipun anak autis memiliki keterbatasan dalam makanan yang dikonsumsi, namun bila pengaturannya tepat maka anak tidak akan kekurangan zat gizi. Demikian sebaliknya, jika pengaturan diet tidak sesuai maka dapat mempengaruhi rendahnya atau berlebihnya asupan zat gizi yang dibutuhkan anak autis. Hal tersebut perlunya peran orang tua untuk teratur, tekun dalam mengatur pola konsumsi anaknya agar tercapainya diet $G F C F$ pada anaknya.

Berdasarkan penelitian yang dilakukan pada anak autis disekolah kebutuhan khusus kota Kediri didapatkan bahwa nilai signifikansi variabel pengetahuan ibu tentang status gizi anak autis adalah $\mathrm{p}=0,03<\propto(0,05)$, artinya variabel pengetahuan mempengaruhi status gizi anak autis. Hal ini menunujukkan bahwa pengetahuan orang tua tentang diet anak autis sangat diperlukan. Karena orang tua yang memiliki anak autis dituntut untuk memberikan diet yang sesuai dengan anak autis. 


\section{Pengaruh Sosial Ekonomi Dengan Status Gizi Anak Autis}

Status sosial ekonomi keluarga berperan dalam penyusunan menu keluarga, serta pengasuhan dan perawatan anak. Tidak ada orang tua yag menginginkan anaknya kurang gizi atau tidak sehat. Namun akibat keterbatasannya menyebabkan orang tua tidak bisa memenuhi keinginannya. Selain sosial ekonomi, beberapa kondisi yang berkaitan dengan pemenuhan gizi antara lain : jangkauan informasi, jangkauan pelayanan, serta persepsi ibu terhadap gizi dan kesehatan yang berkaitan dengan kesehatan (Antma, 2013).

Status sosial ekonomi secara tidak langsung juga akan menentukan pertumbuhan dan perkembangan anak. Hal ini dapat terlihat, pada keluarga dengan status sosial ekonomi tinggi, tentunya pemenuhan kebutuhan gizi akan lebih baik jika dibandingkan dengan keluarga dengan sosial ekonomi yang lebih rendah (Hidayat, 2005).

Berdasarkan hasil analisis data penelitian dengan uji rho sperman's tentang sosial ekonomi orang tua anak dengan autis, di sekolah kebutuhan khusus kota Kediri didapatkan $\mathrm{p}=0,000<$ $\propto(0,05)$ artinya ada hubungan antara sosial ekonomi orang tua dengan status gizi anak autis. Hal ini menunjukkan bahwa status sosial ekonomi keluarga, merupakan dasar terpenuhinya kebutuhan gizi anggota keluarganya. Sebuah keluarga yang salah satu anggota keluarganya menderita autis, memerlukan kecermatan dalam pemenuhan kebutuhan gizinya. Karena anak dengan autis memerlukan diet khusus seperti GFCF agar tidak memperburuk kondisi anak akibat diet yang tidak sesuai. Hal ini memerlukan dukungan ekonomi keluarga untuk membuat rencana pemenuhan diet yang sesuai.

Kemampuan sosial ekonomi keluarga yang tinggi akan mampu untuk menyediakan diet yang sesuai. Sosial ekonomi keluarga yang memadai akan menunjang tumbuh kembang anak, karena orang tua dapat menyediakan semua kebutuhan anak baik yang primer maupun sekunder. Sosial ekonomi juga turut menentukan jenis pangan yang akan dibeli. Sehingga sosial ekonomi merupakan faktor penting bgi kuantitas dan kualitas makanan. Antara penghasilaan dan gizi jelas ada keterkaitan yang menguntungkan. Pengaruh peningkatan sosial ekonomi terhadap perbaikan kesehatan dan kondisi keluarga lain yang mengadakan interaksi dengan status gizi yang berlaku hampir universal (Supariasa, 2012)

Variabel pendapatan atau sosial ekonomi keluarga didapatkan nilai signifikansi $\mathrm{p}=0,04<\propto(0,05)$, artinya variabel variabel sosial ekonomi mempengaruhi status gizi anak autis . Sebagaimana yang telah disebutkan bahwa anak autis membutuhkan diet khusus. Bila hal ini ditunjang dengan dana yang cukup, maka orang tua akan dapat menyusun menu yang sesuai dengan kebutuhan anak. Karena antara pengetahuan, sosial ekonomi dan status gizi merupakan variabel yang saling mempengaruhi.

Jika pengetahuan orang tua yang tinggi tidak didukung dengan sosial ekonomi yang cukup maka, akan mengalami kendala dalam merealisasikan pengetahuannya. Kondisi ini yang perlu mendapatkan perhatian agar status gizi anak dapat terpenuhi dengan baik. Sebagaimana dijelaskan oleh Andriani, bahwa salah satu penyebab tidak langsung dari gizi kurang adalah status sosial ekonomi keluarga. Tingkat sosial ekonomi yang semakin tinggi semakin besar peluangnya untuk bisa berkesempatan untuk hidup dalam lingkungan yang baik dan sehat (Adriani, 2012).

Status gizi yang baik atau status gizi optimal terjadi bila tubuh memproleh cukup zat-zat gizi yang digunakan secara efisien, sehingga memungkinkan pertumbuhan fisik,pertumbuhan otak, 
kemampuan kerja dan kesehatan secara umum pada tingkat setinggi mungkin. Sehingga tidak akan akan muncul status gizi yang berlebih atau status gizi yang kurang. Status gizi kurang terjadi bila tubuh mengalami kekurangan satu atau lebih zat-zat lebih esensial, demikian juga sebaliknya(Almatsier, 2002).

\section{Pengaruh Tingkat Pendidikan Orang Tua Dengan Status Gizi anak autis}

Pendidikan merupakan penuntun manusia untuk berniat dan mengisi kehidupannya yang dapat digunakan untuk mendapatkan informasi sehingga dapat meningkatkan kualitas hidup. Sebagaimana umumnya semakin tinggi tingkat pendidikan seseorang makin mudah menerima informasi dan makin bagus pengetahuan yang dimiliki sehingga penggunaan komunikasi dapat secara efektif akan dapat dilakukannya (Hidayat, 2005).

Berdasarkan hasil analisis data penelitian dengan uji rho sperman's tentang tingkat pendidikan orang tua anak dengan autis, di sekolah kebutuhan khusus kota Kediri didapatkan $\mathrm{p}=0,018<$ $\propto(0,05)$ artinya ada hubungan antara tingkat pendidikan orang tua dan status gizi anak autis. Hal ini menunjukkan bahwa tingkat pendidikan orang tua, merupakan pilar yang penting dalam menentukan pemenuhan gizi keluarga. Orang tua yang mempunyai tingkat pendidikan lebih tinggi akan lebih mudah menerima informasi dari luar terutama tentang cara pengasuhan anak. Pendidikan formal sangat diperlukan dalam meningkatkan pengetrahuan, sehingga dapat mengatur dan mengetahui hubungan antara makanan dan kesehatan. Orang dengan pendidikan yag tinggi akan dapat merencanakan menu makanan yang sehat dan bergizi bagi dirinya dan keluarga dalam upaya memenuhi zat gizi yang diperlukan.

Tingkat pendidikan orang tua adalah pintu gerbang perbaikan gizi anggota keluarga. Karena tingkat pendidikan orang tua yang memadai memungkinkan menerima informasi, khususnya tentang pendidikan gizi dengan lebih mudah. Pendidikan gizi merupakan suatu proses merubah pengetahuan, sikap dan perilaku orang tua untuk mewujudkan status gizi yang baik. Pendidikan gizi keluarga bertujuan mengubah perbuataan-perbuatan yang keliru, yang mengakibatkan bahaya gizi kurang atau lebih (Adriani dan Bambang, 2012).

Selanjutnya hasil analisis variabel tingkat pendidikan, didapatkan bahwa variabel tingkat pendidikan mendapatkan nilai signifikansi $p=0,412>\propto(0,05)$, artinya bahwa tingkat pendidikan tidak mempengaruhi status gizi anak autis. Orang tua yang mempunyai pendidikan tinggi seharusnya mampu menyediakan pemenuhan gizi anaknya dengan baik. Namun hal itu tidak selalu bisa terpenuhi. Hal ini karena orang tua yang berpendidikan tinggi semakin besar peluangnya untuk mendapatkan pekerjaan yang lebih baik. Sehingga orang tua sering kali disibukkan dengan pekerjaannya. Orang tua yang selalu sibuk bekerja mengakibatkan mereka tidak tertarik untuk memperhatikan masalah yang dihadapi anak-anaknya, padahal sebenarnya anak-anak tersebut benar-benar menbutuhkan kasih 122aying orangtua. Demikian juga pada anak dengan autis yang orang tuanya berpendidikan tinggi tidak selalu status gizinya menjadi lebih baik (Adriani, 2012).

\section{Pengaruh Pola aktifitas Anak Dengan Status Gizi Anak Autis}

Anak yang sedang tumbuh dan berkembang mempunyai pola aktifitas yang bervariasi. Aktivitas fisik didefinisikan sebagai setiap gerakan tubuh yang dihasilkan oleh otot-otot skeletal dan menghasilkan peningkatan resting energy expenditure yang bermakna (Ortega,2007). Aktivitas fisik juga dapat didefinisikan sebagai suatu gerakan fisik yang menyebabkan terjadinya kontraksi 
otot. Aktivitas fisik yang dilakukan pada anak sangat penting untuk kesehatan dan perkembangan serta menurunkan risiko untuk terjadi kelebihan berat badan (overweight), obesitas maupun penyakitpenyakit lain yang disebabkan oleh berat badan yang berlebihan (Craft,2008).

Aktivitas fisik pada anak dapat berupa aktivitas sehari-hari baik di rumah maupun di sekolah, kebiasaan, hobi maupun latihan fisik dan olahraga. Untuk memenuhi kebutuhan aktivitas fisik anak, maka baik orangtua maupun guru di sekolah untuk seharusnya menyediakan aktivitas fisik yang terstruktur maupun tidak terstruktur (Craft,2008). Terlebih pada anak dengan autis yang kemampuan sosialisasinya kurang baik, sehingga mengakibatkan mereka terlalu banyak aktivitas yang tidak terkontrol atau cenderung malas bergerak karena disibukkan dengan dunianya sendiri. Bila kondisi ini tidak segera diatasi dapat menyebabkan gangguan status gizi pada anak, baik gizi kurang atau gizi lebih. Tetapi bila orang tua maupun guru disekolah mampu menyediakan aktivitas yang terstruktur dan diet yang sesuai maka status gizi anak akan menjadi baik.

Berdasarkan hasil analisis data penelitian dengan uji rho sperman's tentang pola aktivitas anak autis, di sekolah kebutuhan khusus kota Kediri didapatkan $\mathrm{p}=0,592>\propto(0,05)$ artinya tidak ada hubungan antara pola aktivitas dengan status gizi anak autis. Hal ini menunjukkan bahwa kemampuan orang tua dan guru untuk menyediakan aktivitas anak sudah cukup baik. Dari hasil penelitian yang telah dilakukan didapatkan 28 responden dengan pola aktivitas tergolong aktif, namun terdapat 16 responden $(57,1 \%)$ status gizinya tergolong normal, 10 responden $(35,7 \%)$ status gizinya tergolong kurus dan hanya 1 responden $(3,6 \%)$ status gizinya tergolong berlebih.

Berdasarkan data diatas memberikan gambaran bahwa, aktivitas anak disekolah kebutuhan khusus dikota kediri tergolong aktif, namun sudah cukup terstruktur. Disamping itu pemenuhan gizi sudah cukup seimbang. Sehingga meskipun aktivitas mereka yang sebagian besar tergolong aktif namun status gizinya tergolong normal. Aktivitas fisik yang terstruktur memiliki banyak manfaat untuk anak autis. Beberapa manfaat aktivitas fisik yang terstruktur antara lain : perkembangan kekuatan dan ketahanan dari otot, membangun dan mendorong harga diri, meningkatkan stabilitas dari tubuh, membangun kekuatan otot, jantung dan tulang, mengembangkan keterampilan mengontrol obyek tertentu, mengembangkan keterampilan motorik halus dan motorik kasar, meningkatkan kemampuan berpikir, mengembangkan pengenalan terhadap benda, warna dan bentuk, dan mengembangkan ketahanan dalam sistem kardiovaskular (Kohl,1998)

Hasil analisi variabel aktifitas anak, diperoleh nilai signifikansi $p=0,059>\propto$ $((0,05)$, artinya bahwa tingkat aktivitas tidak mempengaruhi status gizi anak autis. Hal ini karena aktifitas anak autis disekolah kebutuhan khusus kota kediri 96,55\% tergolong aktif, namun terdapat $58,62 \%$ status gizinya normal dan $34,48 \%$ status gizinyatergolong kurus. Responden yang tergolong hiperaktif terdapat 1 responden $(3,45 \%)$, namun status gizinya tergolong normal. Hal ini menunjukkan bahwa status gizi anak autis tidak ditentukan oleh pola aktifitas anak. Meskipun pola aktifitas anak tergolong aktif, tapi bila orag tua mampu menyediakan diet yang seimbang maka kebutuhan gizi anak akan tetap terpenuhi. Kondisi ini ditunjang oleh pengetahuan orang tua tentang diet anak autis 31,05\% tergolong baik. Disamping itu pengaturan aktivitas anak oleh orang tua dirumah dan guru disekolah juga berperan dalam pemenuhan status gizi anak. Orangtua maupun guru di sekolah seharusnya menyediakan aktivitas fisik yang terstruktur maupun tidak terstruktur dengan cermat dan terprogram (Craft,2008). 


\section{Faktor-faktor Yang Mempengaruhi Status Gizi Anak Autis}

Status gizi merupakan keadaan dari tubuh yang diakibatkan oleh keseimbangan antara asupan makanan dan penggunaan zat gizi.Menurut Soekirman dalam Waryana (2010) menyatakan status gizi anak dipengaruhi oleh faktor langsung dan faktor tidak langsung. Faktor langsung tersebut yaitu makanan anak dan penyakit infeksi, Sedangkan faktor tidak langsung yaitu ketahanan pangan dikeluarga, pola pengasuhan anak, serta pelayanan kesehatan dan kesehatan lingkungan, tingkat ekonomi, pendidikan, dan budaya atau kebiasaan.

Berdasarkan penelitian yang dilakukan pada anak autis disekolah kebutuhan khusus kota Kediri didapatkan hasil variabel pengetahuan mempengaruhi status gizi anak autis. Variabel pendapatan atau sosial ekonomi keluarga juga mempengaruhi status gizi anak autis . Hal ini menunujukkan bahwa pengetahuan orang tua tentang diet anak autis sangat diperlukan. Karena orang tua yang memiliki anak autis dituntut untuk memberikan diet yang sesuai dengan anak autis.Salah terapi untuk meringankan kondisi autisme pada anak adalah pengaturan gizi dan makanan. Sebagaimana yang telah disebutkan bahwa anak autis membutuhkan diet khusus. Bila hal ini ditunjang dengan dana yang cukup, maka orang tua akan dapat menyusun menu yang sesuai dengan kebutuhan anak. Karena antara pengetahuan, sosial ekonomi dan status gizi merupakan variabel yang saling mempengaruhi.

Jika pengetahuan orang tua yang tinggi tidak didukung dengan sosial ekonomi yang cukup maka, akan mengalami kendala dalam merealisasikan pengetahuannya. Kondisi ini yang perlu mendapatkan perhatian agar status gizi anak dapat terpenuhi dengan baik. Sebagaimana dijelaskan oleh Andriani, bahwa salah satu penyebab tidak langsung dari gizi kurang adalah status sosial ekonomi keluarga. Tingkat sosial ekonomi yang semakin tinggi semakin besar peluangnya untuk bisa berkesempatan untuk hidup dalam lingkungan yang baik dan sehat (Adriani, 2012).

Status gizi yang baik atau status gizi optimal terjadi bila tubuh memproleh cukup zat-zat gizi yang digunakan secara efisien, sehingga memungkinkan pertumbuhan fisik,pertumbuhan otak, kemampuan kerja dan kesehatan secara umum pada tingkat setinggi mungkin. Sehingga tidak akan akan muncul status gizi yang berlebih atau status gizi yang kurang. Status gizi kurang terjadi bila tubuh mengalami kekurangan satu atau lebih zat-zat lebih esensial, demikian juga sebaliknya(Almatsier, 2002).

Selanjutnya hasil analisis variabel tingkat pendidikan, didapatkan bahwa variabel tingkat pendidikan mendapatkan nilai signifikansi $p=0,412>\propto(0,05)$, artinya bahwa tingkat pendidikan tidak mempengaruhi status gizi anak autis. Orang tua yang mempunyai pendidikan tinggi seharusnya mampu menyediakan pemenuhan gizi anaknya dengan baik. Namun hal itu tidak selalu bisa terpenuhi. Hal ini karena orang tua yang berpendidikan tinggi semakin besar peluangnya untuk mendapatkan pekerjaan yang lebih baik. Sehingga orang tua sering kali disibukkan dengan pekerjaannya. Orang tua yang selalu sibuk bekerja mengakibatkan mereka tidak tertarik untuk memperhatikan masalah yang dihadapi anak-anaknya, padahal sebenarnya anak-anak tersebut benar-benar menbutuhkan kasih 124aying orangtua. Demikian juga pada anak dengan autis yang orang tuanya berpendidikan tinggi tidak selalu status gizinya menjadi lebih baik (Adriani, 2012).

Hasil analisi variabel aktifitas anak, diperoleh nilai signifikansi $p=0,059>\propto$ $((0,05)$, artinya bahwa tingkat aktivitas tidak mempengaruhi status gizi anak autis. 
Hal ini karena aktifitas anak autis disekolah kebutuhan khusus kota kediri 96,55\% tergolong aktif, namun terdapat $58,62 \%$ status gizinya normal dan $34,48 \%$ status gizinyatergolong kurus. Responden yang tergolong hiperaktif terdapat 1 responden $(3,45 \%)$, namun status gizinya tergolong normal. Hal ini menunjukkan bahwa status gizi anak autis tidak ditentukan oleh pola aktifitas anak. Meskipun pola aktifitas anak tergolong aktif, tapi bila orag tua mampu menyediakan diet yang seimbang maka kebutuhan gizi anak akan tetap terpenuhi. Kondisi ini ditunjang oleh pengetahuan orang tua tentang diet anak autis 31,05\% tergolong baik. Disamping itu pengaturan aktivitas anak oleh orang tua dirumah dan guru disekolah juga berperan dalam pemenuhan status gizi anak. Orangtua maupun guru di sekolah seharusnya menyediakan aktivitas fisik yang terstruktur maupun tidak terstruktur dengan cermat dan terprogram (Craft,2008).

\section{KESIMPULAN}

1. Ada pengaruh antara tingkat pengetahuan orang tua dengan status gizi anak autis di sekolah kebutuhan khusus kota Kediri

2. Ada pengaruh antara sosial ekonomi orang taua dengan status gizi anak autis di sekolah kebutuhan khusus kota Kediri

3. Tidak ada pengaruh antara tingkat pendidikan orang tua dengan status gizi anak autis di sekolah kebutuhan khusus kota Kediri

4. Tidak ada pengaruh anatara pola aktifitas anak dengan status gizi anak autis di sekolah kebutuhan khusus kota Kediri

5. Faktor-faktor yang mempengaruhi status gizi anak autis dikota Kediri adalah pengetahuan orang tua tentang gizi dan sosial ekonomi orang tua.
Saran

1. Pengetahuan orang tua tentang gizi anak autis perlu terus di up date dan ditingkatkan, seiring dengan pesatnya produk makanan bagi anak di masyarakat.

2. Kerja sama antara orang tua dan guru disekolah perlu terus dibina, sehingga tercipta kinerja yang sinergis untuk memberikan asuhan yang optimal bagi anak autis baik dirumah dan disekolah untuk memberikan pemenuhan gizi yang seimbang.

3. Perlunya pembinaan mental bagi orang tua, untuk memberikan suport dalam mengasuh anak yang berkebutuhan khusus sehingga mampu memberikan dorongan bagi orang tua dalam memberikan asuhan yang optimal.

\section{DAFTAR PUSTAKA}

Adriani, M dan Wirjatmadi, B. (2012) Pengantar Gizi Masyarakat. Jakarta : Kencana

Almatsier, S. (2009) Prinsip Dasar Ilmu Gizi. Jakarta: PT.Gramedia Pustaka Utama

Andyca, Febby. (2012) Faktor-faktor yang Berhubungan dengan Status Gizi pada Anak Autisdi Tiga Rumah Autis(Bekasi, Tanjung Priuk, Depok) dan Klinik Tumbuh Kembang Kreibel Depok. Skripsi, Program Sarjana FKM UI, Depok

Aprila, Eldyna. (2012) Pengetahuan Orang Tua tentang PemenuhanKebutuhan Nutrisi pada Anak Autisme di Yayasan Tali Kasih dan Yayasan Kidz Smile Medan. Skripsi, Program Sarjana FKM USU, Sumatera Utara

Craft, DH, Smith C.L, Active play Fun Physical Activity For Young Children.(2008), Cortland, NG : Active Play Book

Curtin, Carol et all. (2005) Prevalence of Overweight in Children and 
Adolescents with Attention Deficit Hyperactivity and Autism Spectrum Disoders: a ChartReview. BMC Pediatrics

Curtin, Carol et all. (2010) Prevalence of Obesity in Children with Autism: a Secondary Data Analysisusing Nationally Representative data from the National Survey of Children's Health. BMC Pediatrics

Dinas Komunikasi dan Informatika, UMR Jawa Timur 2013, Diakses tanggal 6 Juni 2016

Direktorat Bina Gizi, (2011) Keputusan Menteri Kesehatan Republik Indonesia Nomor 1995/MENKES/SK/XII/2010

Tentang Standar Antropometri Penilaian Status Gizi Anak: Jakarta : KEMENKES RI

Halgin, Richard P. (2010) Psikologi Abnormal. Jakarta: Salemba Medika

Hidayat, A.Aziz Alimul. (2012) Metode Penelitian Kebidanan Teknik Analisis Data. Jakarta: Salemba Medika

(2008) Pengantar Ilmu

Keperawatan Anak. Jakarta: Salemba Medika

Jouret, Beatrice et all. (2007) Factors Associated with Overweight in Preschool-Age Childrenin Southwestern France. Am J Clin Nutr; 85: 1643-9

Kohl H, Hobbs K.(1998) Development of Physical Activity Behaviors Among Children and Adaloscent. Pediatrics

Li, Ming et all. (2010) Dietary Habits and Overweight/Obesity in Adolesecents in Xia'an City, China. Asia Pac J Clin Nutr; 191: 76-82

Malahayati. (2010) Cantik Sehat Energik. Yogjakarta:Galangpress

Manshur, Herawati. (2009) Psikologi Ibu dan Anak untuk Kebidanan. Jakarta: Salemba Medika

Mashabi NA, Tajudin NR. (2009) Hubungan antara Pengetahuan Gizi Ibu dengan Pola Makan anak Autis. Makara, Kesehatan Vol.13 No.2:8486
Mujiyanti, Dwi Murni. (2011) Tingkat Pengetahuan Ibu dan Pola Konsumsi pada Anak Autisdi Kota Bogor. Skripsi, Program Sarjana PKM IPB, Bogor

Notoatmojo, Soekidjo. (2010) Metode Penilitian Kesehatan. Jakarta: Rineka Cipta

Nursalam. (2011) Konsep dan Penerapan Metodologi Penelitian Ilmu Keperwatan Pedoman Skripsi, Tesis, dan Instrumen Penelitian Keperawatan. Jakarta: Salemba Medika . (2009) Konsep dan Penerapan Metodologi Penelitian Ilmu Keperawatan. Jakarta: Salemba Medika

Ortega FB, Ruiz JR, Castilo M.J.(2007) Physical Fitness in Child Hood and Adaloscent, a Power Full of Health Marker of Health J Ober

Peeters, Theo. (2004) Autisme. Jakarta: PT. Dian Rakyat

Ramayulis, Rita dan Lilis, Christine Lesmana. (2008) 17 Alternatif untuk Lansing. Jakarta: Penebar Swadaya

Rosyada, Prima. (2012) Hubungan Konsumsi Gluten dan Kasein dengan Status Gizi pada Anak Autis di Kota Semarang.

Universitas Muhammadiyah Semarang

Rusmil, Kusnandi. (2006) Stimulasi, Deteksi dan Intervansi Dini Tumbuh Kembang Anak. Jakarta: Departemen Kesehatan R.I

Sedyaningsih, Endang Rahayu. (2011) Kepmenkes RI No.1995/MENKES/ SK/XII/2010 Tentang Standar Antropometri Penilaian Status Gizi Anak. Jakarta: Menteri Kesehatan

Sugiarmin,M. (2005) Individu dengan Gangguan Autisme. PLB UPI

Sugiyono. (2007) Statiska untuk Penelitian. Bandung: CV.Alfabeta

Sunu, Christoper. (2012) Unlocking Autism. Yogjakarta: Lintang Terbit

Supariasa, I Dewa Nyoman, dkk. (2012) Ilmu Gizi. Jakarta: EGC 
Undang-undang Republik Indonesia Nomor 20 Tahun 2003 Tentang Sistem Pendidikan Nasional \& Undang-undang Republik Indonesia Nomor 14 Tahun 2005 tentang Guru dan Dosen-Jakarta: 2007

Wahyu, Genis Ginanjar. (2009) Obesitas pada Anak. Yogjakarta: PT.Bentang Pustaka

Winarno,Teguh. (2011) Media dan Teknologi Pendidikan. Tugas Observasi, Program PAI

Wong, Donna L. (2009) Buku Ajar Keperawatan Pediatrik. Jakarta: EGC

Yatim, Faisal. (2007) Autisme Suatu Gangguan Jiwa pada Anak-anak. Jakarta: Pustaka Populer Obor

Zahriasah, Aminatun. (2010) Analisa Rambut untuk Menentukan Suplemen Tepat Bagi Anak Autis. Jakarta : Financial Hall Graha Naga

Zimmermann, Michael et all. (2004) Detection of Overweight and Obesity in National Sample of 6-12-y-old Swiss Children: Accuracy and Validity of Reference Values for Body Mass Index from the US Centers for Disease Control and Prevention and the International Obesity Task Force. Am J Clin Nutr ; 79 : 838-843 